\title{
Upgrading qualifications as a means of professional advancement and success
}

\author{
Elena Makeeva $^{1 *}$, Yulia Lopukhova ${ }^{2}$, and Josef Spaubeck ${ }^{3}$ \\ ${ }^{1}$ Samara State University of Social Sciences and Education, Department of English Philology and \\ Intercultural Communication, 443090, Blukhera str. 25, Samara, Russia \\ ${ }^{2}$ Samara State Technical University, Department of Pedagogics, Intercultural Communication and \\ Russian as a Foreign Language, 443100, Molodogvardeyskaya str. 244, Samara, Russia \\ ${ }^{3}$ Zuyd University of Applied Science, International Business School, 6200 AP Maastricht \\ Brusselseweg 150, the Netherlands
}

\begin{abstract}
The aim of this study was to find out whether upgrading university teachers' qualifications would enhance their professional advancement and success. To address these issues, this paper presents a research held in Samara State Technical University for three years. The participants of the study were 15 university teachers who were staff members of the Department of Linguistics, Intercultural Communication and Russian as a Foreign Language. These teachers were given an opportunity to obtain new competencies aimed at implementing the university strategy by taking additional training programmes and upgrading qualifications courses. This paper aims explores these teachers experiences and outcomes and demonstrates that professional development is not always connected with mastering teaching skills but can serve as a means of promoting university strategy and achieving personal goals.
\end{abstract}

\section{Introduction}

The arrival of the new millennium brought about considerable changes all around the world. In most countries, the role and functions of higher educational institutions and universities started to transform as well, bringing about new educational strategies and programmes, curricula modernisation, digital technologies and other innovations. Almost every country in the world has undertaken some form of higher education reform over the past two decades [1]. Professional development of university teachers has also been affected by these reforms and university teachers' theoretical and practical training (retraining) has recently become a "widespread trend in many countries" [2].

Teachers' professional development and educational reform are reciprocal. Teachers' professional development cannot succeed isolated from major educational reform, or without policy and organizational support, because changes need contexts and conditions [3]. Equally truly, educational reform will not succeed without teachers' involvement and their successful professional development [4]. Still, professional advancement and success

\footnotetext{
* Corresponding author: helenmckey2205@gmail.com
} 
of university teachers also depends on their professional development. Thus, professional development should not be studied only from the point of view of its benefits to educational process in general but analysed as a means of promoting university strategy and achieving personal goals.

\section{Literature review}

The professional development of teachers is studied and presented in the relevant literature in many different ways [5]. Most researchers agree that no matter what professional education university teachers initially received, it cannot be expected to prepare them for all the challenges they will face throughout their careers [6]. Thus, Paper [7] states that theoretical university training is essential to teach subject matter but only further in-service training and upgrading qualifications will help in mastering teaching skills. Supporting this idea, Paper [8] adds that a teacher has to constantly upgrade his or her qualifications, continuously work on professional self-improvement and benefit from innovative pedagogical experiences. At the same time, most education systems likewise aim to provide teachers with opportunities for professional development in order to maintain a high standard of teaching and to retain a high-quality teacher workforce [6] For this reason, such forms of professional development for teachers that are built on collaboration, collegial interactions, and the fostering of relationships are promoted [9].

In earlier seminal works, American scholars described such levels of impact of training as participants' reaction to the training; participants' learning (change in attitudes, knowledge or skills); participants' behavioural change; and results at student or organisational level [10] or, in the extended later version, participants' reactions; participants' learning; organisation support and change; participants' use of new knowledge and skills; and student learning outcomes [11]

Most European educators also stress a need to establish the effectiveness of higher education teachers' training in improving university teaching. [12]. Thus, one of the most famous quantitative studies conducted in Great Britain examined the impact of training of university teachers on approaches to teaching, teaching skills and approaches to learning of their students. A training group of teachers and their students were studied at the start of their training and one year later. They report evidence of a range of positive changes in teachers in the training group, and in their students, and a contrasting lack of change, or negative changes, in untrained teachers from the control group [13].

Enhancing teacher professional development is also a priority in the Netherlands [14]. There is a lot of attention given to the professional development of teacher educators as a condition for improvement of the quality of teacher education and the implementation of the national curriculum [15]. Participation in professional development is high among fulltime teachers. Recent measures aim to raise teacher qualification levels and attract more candidates to the career. Continuing professional development is optional but encouraged through a range of measures. Three goals are formulated for the professional development of teacher educators: 1 . To raise the expertise of the staff so they will be able to function in a variety of tasks. 2. To relate professional development to developments in society, education and educational research. 3. To improve the potential for innovation in teacher education [15].

In Russia, professional development of university teachers usually takes form of an educational or work-related training and is referred to as "upgrading qualifications". Framing the concept of long-term social and economic development of the Russian Federation to 2020, the state program "Development of Education in the Russian Federation for 2013-2020" emphasizes a comprehensive support of pedagogical strategies aimed at creating innovative programs and environments for education, which requires a 
rethinking of stereotypes on the innovative pedagogical experience aimed at the professional development of the teacher [16]. Professional development of the teacher is understood as an ongoing process of a directed personal development due to a successful performance of one's professional duties and actions [17].

At the same time, most innovations introduced recently to the system of Russian higher education are aimed at transforming universities into some type of independent enterprises earning money by their educational and other activities. It means that university teacher professional development should not be aimed at mastering professional skills only but at acquiring new competences connected with raising university funds by introducing innovative projects, attracting foreign students to study at Russian universities, winning grants and performing other professional duties and actions. As traditional upgrading qualifications courses are not meant to fulfil these tasks, only new forms of training programmes might help university teachers to become successful in this new reality.

\section{Materials and methods}

\subsection{Participants}

The participants of the study were 15 university teachers who worked on a full-time basis at Samara State Technical University (further referred to as SGTU) and were staff members of the Department of Linguistics, Intercultural Communication and Russian as a Foreign Language (further referred to as the LIC\&RFL Department): 1 professor, 12 associate professors and 2 senior lecturers. Almost all these teachers had participated in upgrading qualifications courses for university teachers before this research was undertaken (before 2017). Most of those courses focused on enhancing teaching quality in higher education, on updating individuals' knowledge of a subject in light of recent advances in the area or just on exchanging information and expertise among teachers. The courses certified these teachers' didactic competences though the effect of this training on their students' test scores or success was never studied. On average every teacher participated in one course every four or five years.

However, in the last 3 years these 15 university teachers participated in 114 professional development programmes or upgrading qualifications courses of 5 different types listed below. For the quantitative part of this study, these teachers were further divided into four groups, depending on how much training for university teachers they had. Academic staff who had participated in different programmes and took various courses between September 2017 and February 2020 were then invited to contribute to this research that collected data via interviews and a survey. In order to understand the teachers' experiences, open qualitative approaches to data analysis were used. The authors also studied official data summarizing the number of papers published, conferences attended, course-books and other teaching materials designed, "guest-professor" invitations, grant applications and submissions, etc. The so-called "academic staff rating" officially published in SGTU also served as a source for conclusions.

\subsection{Courses}

The courses university teachers attended withing this period were either compulsory courses organised by the University authorities (participation in such activities were required for teacher certification) or non-compulsory programmes developed by the members of Department in question together with their Erasmus + partners. Several teachers also took independent courses or programmes in other higher educational institutions or on 
online platforms at their own will. The researchers divide all these courses and programmes into the following five types:

1) Type 1. Obligatory General Courses required for all university teaching staff by the Federal Law "On Education in the Russian Federation" (hereinafter - the "Federal Law on Education" [18]) and existing Federal educational standards included the following three upgrading qualifications courses (taught by SGTU specialists, all on a free basis):

- First aid treatment skills (36 teaching hours, 2018 or 2019; abbreviated as FATS in Table 1);

- Information and communication technologies in university educational online environment (36 teaching hours; 2018 or 2019; abbreviated as ICT in Table 1);

- Theoretical and practical aspects of teaching students with special needs (16 teaching hours; abbreviated as TPAT in Table 1).

The training was given jointly to all the relevant subject teachers and all teachers had to (and did) participate in the courses of Type 1.

2) Type 2. Additional Free Courses organized by the LIC\&RFL Department and its foreign partners from Zuyd University (all on a free basis and on a voluntary basis for teachers but held outside their normal working hours) [19]:

- The basics of financial literacy for non-business teachers (72 teaching hours; 2018; abbreviated as BFL in Table 1);

- Innovations in teaching and learning foreign languages (144 teaching hours; 2019; abbreviated as ITLFL in Table 1).

3) Type 3. Upgrading qualifications courses held within the frames of the IDUTE programme (International Dimension of University Teacher Education) which was introduced in SSTU by the LIC\&RFL Department representatives together with its Erasmus+ partners, and aims to enhance the international dimensions of various components of University teacher education programmes and to provide University teachers with greater global competences [20].

The programme came into force in the autumn term of 2017 . It has been designed as eight separate 16/36/72-hour modules gradually offered for SSTU teachers. The teachers are able to choose 2-4 modules a year thus covering the whole programme within the period of 23 years. The following modules of the IDUTE programme have been successfully realized, some are in progress at the moment againg, and the rest will hopefully be repeated soon:

- Module 1. Summer Schools (16 teaching hours: 2017, 2018 \& 2019);

- Module 2. CLIL Methodology in a Technical Classroom (72 teaching hours; 2018 \& 2019);

- Module 3. Making Successful Applications for International Grants (72 teaching hours; 2018 \& 2019);

- Module 4. International Conferences and Networking: Participating \& Organizing (16 teaching hours; 2019);

- Module 5. How to Write an Article in an International Journal (36 teaching hours ; 2019).

Such modules of this programme as Module 6 (Buddy Programmes \& International Field Trips, 16 hours); Module 7 (Digitalization of Education: Online Courses for Foreign Students, 72 hours) \& Module 8 (Developing Double-Degree Programmes, 16 hours) are still in development because their launching was suspended owing to the ongoing COVID19 pandemic).

4) Type 4. Massive open online courses presented on such internationally recognized platforms as Coursera, FutureLearn, EdX, Udemy, etc. and online courses suggested by Epigeum Online Course System (Oxford University Press), Online Education \& Teaching Courses (Harvard University), the TEFLorg and others. All courses were taken on a voluntary basis and found by the teachers themselves depending on their professional 
interests. These courses aimed mostly at developing language and teaching skills. Teachers who are the subjects of our study have taken different courses within the investigated period (e.g. "English for Business and Entrepreneurship" (Coursera), "Active learning for online or blended delivery" (Epigeum Online Course System), "140-hour Premier TEFL course" (TEFLorg), "English as a medium of instruction for academics" (FutureLearn), "Writing, presenting and submitting scientific papers in English" (EdX) and the like) so in Table 1 we divide them only into free courses and fee-paying courses (paid voluntary by the teachers themselves). These programmes are intentionally designed for upgrading teacher qualifications and developing special teaching skills. We refer these courses to classical professional development courses which are aimed, according to most researchers, at mastering and applying innovative pedagogical experience for an intensive development and realization of one's creative potential [17].

5) Type 5. Face-to-face courses and overseas training (partially financed either by SGTU or grant funds and partially paid for by the teachers) in Atlantic Language Galway, Zuyd University of Applied Science and Ludwigsburg Pedagogical Institute.

\subsection{Quantitative characteristics}

Table 1 shows what upgrading qualifications courses and professional development programmes were taken by the teachers of LIC\&RFL Department during the period of 2017-2019 (see Table 1).

Table 1. Upgrading qualifications courses as taken by the teachers of LIC\&RFL Department in 2017-2019.

\begin{tabular}{|c|c|c|c|c|c|c|c|c|c|c|c|c|c|}
\hline \multirow{2}{*}{ Teurses } & \multicolumn{3}{|c|}{$\begin{array}{l}\text { 1) Obligatory } \\
\text { General } \\
\text { Courses }\end{array}$} & \multicolumn{2}{|c|}{$\begin{array}{c}\text { 2) } \\
\text { Additio } \\
\text { nal Free } \\
\text { Courses }\end{array}$} & \multicolumn{5}{|c|}{$\begin{array}{l}\text { 3) IDUTE programme } \\
\text { courses }\end{array}$} & \multicolumn{2}{|c|}{$\begin{array}{l}\text { 4) MOOCs } \\
\text { \& Online } \\
\text { courses }\end{array}$} & \multirow{2}{*}{$\begin{array}{c}5) \\
\text { F2 } \\
\text { F } \\
\end{array}$} \\
\hline & $\begin{array}{l}\mathrm{F} \\
\mathrm{A} \\
\mathrm{T} \\
\mathrm{S}\end{array}$ & $\begin{array}{c}\mathrm{IC} \\
\mathrm{T}\end{array}$ & $\begin{array}{l}\mathrm{T} \\
\mathrm{P} \\
\mathrm{A} \\
\mathrm{T}\end{array}$ & $\begin{array}{l}\text { B } \\
\text { F } \\
\text { L }\end{array}$ & $\begin{array}{l}\text { IT } \\
\text { L } \\
\text { F } \\
\text { L }\end{array}$ & $\begin{array}{c}M \\
1\end{array}$ & $\begin{array}{c}\mathrm{M} \\
2\end{array}$ & $\begin{array}{c}M \\
3\end{array}$ & $\begin{array}{c}M \\
4\end{array}$ & $\begin{array}{c}M \\
5\end{array}$ & free & paid & \\
\hline T1 & + & + & + & & & & & & & & & & \\
\hline $\mathrm{T} 2$ & + & + & + & & & & & & & & & & \\
\hline T3 & + & + & + & & + & & & & & & & & \\
\hline T4 & + & + & + & & & & + & & & & & & \\
\hline T5 & + & + & + & & + & & & & & & & & \\
\hline T6 & + & + & + & + & + & + & & & & & & & \\
\hline $\mathrm{T} 7$ & + & + & + & & + & & & + & & & + & & + \\
\hline $\mathrm{T} 8$ & + & + & + & + & + & & + & + & & & & & \\
\hline T9 & + & + & + & + & & + & + & + & & & + & & + \\
\hline $\mathrm{T} 10$ & + & + & + & + & + & + & & & + & + & + & & \\
\hline T11 & + & + & + & + & + & & + & & + & & + & + & + \\
\hline T12 & + & + & + & + & + & + & + & + & + & + & + & & + \\
\hline $\mathrm{T} 13$ & + & + & + & + & + & + & + & + & + & & + & + & + \\
\hline $\mathrm{T} 14$ & + & + & + & + & + & + & + & + & + & + & & + & + \\
\hline $\mathrm{T} 15$ & + & + & + & + & + & + & + & + & + & + & + & + & + \\
\hline
\end{tabular}


While analyzing the qualitative and quantitative information related to the courses completed, the authors considered it appropriate to refer to the teachers as T1, T2 and so on (starting from those with the least number of courses done) for the sake of personal animosity and alongside with that divide them into the groups according to the number and type of programmes they covered. It helped investigate and see the coherent dependence of their professional advancement and success upon the courses and further demonstrate it in the analytical part of this study.

As seen in Table 1, five teachers (thereinafter Red Group) took only obligatory general courses. They did it because it was required by normative documents to sustain their employment and considered other programmes redundant. Three teachers (Yellow Group) upgraded their qualifications while completing both obligatory courses and 2-4 other courses to gain their rating points. Three teachers (Blue Group) completed more than a half of additional courses for both their rating points and hope for further professional success. Four teachers (Green Group) completed almost all the courses including some paid professional development programmes as they were sure it will help them succeed professionally and, most likely, get salary increase as well.

\section{Results}

This preliminary work had been done by the researchers by May 2020. In June 2020, the university academic staff rating was published. It took into account not only upgrading qualifications courses and professional development programs but also other important results university teachers achieved during the past academic year (scientific papers published, conferences attended, course-books and other teaching materials designed, grant applications and submissions, paid educational activities for prospect students organized and so on). At the same time, the process of job cuts was launched at the university in order to achieve a balance between the number of students and university teachers required by Russian normative documents. Those with the lowest rating score were affected.

Table 2. Upgrading qualifications impact on university teachers further professional advancement and success.

\begin{tabular}{|c|c|c|c|c|c|c|c|c|c|c|}
\hline & $\begin{array}{c}\text { Lost } \\
\text { their } \\
\text { jobs }\end{array}$ & $\begin{array}{c}\text { Incom } \\
\text { e was } \\
\text { reduce } \\
\mathrm{d}^{1}\end{array}$ & $\begin{array}{c}\text { No } \\
\text { chan } \\
\text { ges }\end{array}$ & $\begin{array}{c}\text { intern } \\
\text { ationa } \\
\text { hed } \\
\text { paper } \\
\text { s }\end{array}$ & $\begin{array}{c}\text { Organ } \\
\text { ized } \\
\text { innov } \\
\text { ative } \\
\text { projec } \\
\text { ts }\end{array}$ & $\begin{array}{c}\text { Organ } \\
\text { ized } \\
\text { intern } \\
\text { ationa } \\
1 \\
\text { activit } \\
\text { ies }\end{array}$ & $\begin{array}{c}\text { Recei } \\
\text { ved } \\
\text { grants }\end{array}$ & $\begin{array}{c}\text { Raise } \\
\text { unive } \\
\text { rity } \\
\text { funds } \\
2\end{array}$ & $\begin{array}{c}\text { Inco } \\
\text { me } \\
\text { increa }_{\text {sed }}^{3}\end{array}$ \\
\hline Red Group & 40 & 40 & 10 & & - & - & - & - & - \\
\hline $\begin{array}{c}\text { Yellow } \\
\text { Group }\end{array}$ & - & 33 & 33 & 33 & - & - & - & - & - \\
\hline Blue Group & - & - & - & 66 & 66 & - & 33 & 33 & 66 \\
\hline Green group & - & - & - & 100 & 50 & 50 & 75 & 75 & 100 \\
\hline
\end{tabular}

${ }^{1}$ because they have to work only on a half-time basis

${ }^{2}$ excluding grants money

${ }^{3}$ because they either receive supplement for their high rating score or grants funding 
Table 2 summarizes upgrading qualifications impact on university teachers further professional advancement and success (see Table 2).

To sum it up, university teachers from Blue and Green groups did their best and spent a great amount of their non-working time while attending upgrading qualifications courses and professional development programmes which were not directly connected with their teaching activities. As a result, they collectively managed to publish 12 scientific papers in internationally recognized journals and two, create two online courses in the university electronic environment, organize a summer school for students from partner universities, launch a new international double-degree bachelor programme, find new international partners and get an Erasmus + grant for 2020-2022 an so on. Their personal rating score and the Department rating were the highest among other humanitarian departments of the technical university which led to increase in these teachers' salaries as well.

\section{Conclusion}

The results indicate that upgrading qualifications courses and professional development programmes exert a far-reaching effect on professional advancement and success and can serve a number of objectives.

The research held in Samara State Technical University revealed that there are obligatory courses required for teachers to complete that give nothing to further professional advancement. On the other hand, university authorities and department heads are able to organize courses of a new format developing such competencies of university teachers that are not closely connected with their teaching skills but that can as a means of promoting university strategy and achieving personal goals.

\section{References}

1. E.M. Camburn, S.W. Han, J. of Ed. Change, 16 (4), 511-533 (2015)

2. L. Postareff, S. Lindblom-Ylänne, A. Nevgi, Teaching \& Teach. Educ, 23 (5), 557571, DOI: 10.1016/j.tate.2006.11.013

3. E. Villegas-Reimers, Teacher professional development: an international review of the literature (Paris, International Institute for Educational Planning, 2003)

4. H. Zhu, Prof. Dev. in Ed., 36 (1-2), 373-391, DOI:10.1080/19415250903457604 (2010)

5. B. Avalos, Teaching \& Teach. Educ, 27 (1), 10-20, ttps://doi.org/10.1016/j.tate.2010.08.007, (2011)

6. Creating Effective Teaching and Learning Environments: First Results from TALIS. Teaching and Learning International Survey, http://www.oecd.org/education/school/43023606.pdf (OECD, 2009)

7. J.P. Farrell, J. Oliveira, Teachers in Developing Countries: Improving Effectiveness and Managing Costs, 175-186 (Washington, DC: World Bank, 1993)

8. O.V. Tulupova, E.A. Afonina, A.A. Tsahaeva, S.A. Alieva, B.S. Kasumova, J. of Soc. Sc. Research, 5, 142-145, DOI: 10.32861/jssr.spi5.142.145 (2018)

9. J.H. Van Driel, A. Berry, Ed. Researcher, 41 (1), 26-28, https://doi.org/10.3102/0013189X11431010 (2012)

10. D.L. Kirkpatrick, Evaluating training programmes. The four levels (San Francisco: Berett-Koehler, 1994) 
11. T.R. Guskey, Evaluating professional development (Thousand Oaks, CA: Corwin Press 2000)

12. A. Gilbert, G. Gibbs, Res. \& Dev. in Higher Ed., 21, 131-143 (1999)

13. G. Gibbs, M. Coffey, Active Learn in Higher Ed., 5(1), 87-100, DOI: $10.1177 / 1469787404040463$ (2004)

14. Netherlands 2016: Foundations for the Future, Reviews of National Policies for Education (OECD Publishing, Paris. http://dx.doi.org/10.1787/9789264257658-en, 2016)

15. B. Koster, M. Snoek, J. of In-Service Ed., 24 (3), 547-560, DOI: 10.1080/13674589800200053 (2006)

16. M.S. Britkevich, Sc. Opinion: Sc. J. St., 12, 257-263 (2013)

17. E.I. Kustova, L.Z. Karavanova, S.G. Zelgin, L.P. Yarkina, E.A. Malykh, E.V. Kozhina, Revista ESPACIOS, 39 (49) (2018)

18. Federal Law "On Education in the Russian Federation" No 273-FZ of 29.12.2012 (as amended on July 3, 2016, No 313-FZ) (accessed at: http://publication.pravo.gov.ru/Document/View/0001201607040089?index=1\&rangeSi $\mathrm{ze}=1)$

19. J. Lopukhova, E. Makeeva, Adv. in Intel. Systems and Comp., 917, 514-524, https://doi.org/10.1007/978-3-030-11935-5_49 (2019)

20. Y. Lopukhova, E. Makeeva, K. Kuzovenkova, SOCIETY. INTEGRATION. EDUCATION: Proceedings of the International Scientific Conference, 510-520, DOI: http://dx.doi.org/10.17770/sie2020vol1.4986 (2020) 